\title{
The Risk Assessment of Debris Flow Hazards in Banshanmen Gully Based on the Entropy Weight-Normal Cloud Method
}

\author{
X. B. Gu ${ }^{1},{ }^{1}$ S. T. Wu, ${ }^{1,2}$ X. J. Ji, ${ }^{1}$ and Y. H. $\mathrm{Zhu}^{3}$ \\ ${ }^{1}$ School of Civil Engineering, Nanyang Institute of Technology, Nanyang, Henan 473004, China \\ ${ }^{2}$ College of Aerospace Engineering, Nanjing University of Aeronautics and Astronautics, Nanjing, China 210016 \\ ${ }^{3}$ School of Civil Engineering, Neijiang Normal College, NeiJiang, China \\ Correspondence should be addressed to X. B. Gu; guxinbao11@163.com
}

Received 15 July 2020; Revised 16 November 2020; Accepted 11 December 2020; Published 8 January 2021

Academic Editor: Giuseppe Oliveto

Copyright $(92021$ X. B. Gu et al. This is an open access article distributed under the Creative Commons Attribution License, which permits unrestricted use, distribution, and reproduction in any medium, provided the original work is properly cited.

\begin{abstract}
The debris flow is one of the geological hazards; its occurrence is complex, fuzzy, and random. And it is affected by many indices; a new multi-index assessment method is proposed to analyze the risk level of debris flow based on the entropy weight-normal cloud model in Banshanmen gully. The index weight is calculated by using the entropy weight method. Then, the certainty degree of each index belonging to the corresponding cloud is obtained by using the cloud model. The final risk level of debris flow is determined according to the synthetic certainty degree. The conclusions are drawn that the method is feasible and accurate rate of risk estimation for debris flow is very high, so a new method and thoughts for the risk assessment of debris flow can be provided in the future.
\end{abstract}

\section{Introduction}

The debris flow is one of the geological hazards; it is defined as a special flood [1] with a great deal of silt and rocks induced from the rainfall and topography. The debris flow usually happens in a mountainous area; it is characterized as short time, strong destructiveness, wide distribution, and high occurrence frequency [2], so the debris flow brings great harms to the safety of life, property, and infrastructure. To prevent harm, the risk assessment and prediction of debris flow become an important issue [3]; researchers [4] in different countries provided methods and methodologies to determine the risk level of debris flow in the past few decades. All these methods are divided into four types: statistical analysis method [5], artificial intelligence methods [6], numerical simulation [7], and other methods [8]. The grey theory [9], the neural network [10], fuzzy mathematics [11], extension theory [12], and hierarchical analysis [13] are widely applied to assess the risk level of debris flow, and they all belong to the above four types. Especially, GIS theory [14] and numerical simulations are gradually applied to analyze the risk level of debris flow as the development of science and technology; for example, the risk level of a small watershed in Sanyanyu is assessed by Yu [15] by using Flac3D; hazard assessment of debris flow disaster in Zhouqu Nanyu gully is assessed by Guo [16] using the grey theory; hazard assessment of debris flow along the highway of a high altitude cold and intensity regions with aid of ArcGIS are performed by Zhang [17]; although the reliability and accuracy [18] of risk assessment about debris flow has improved enormously by using the above methods; however, they still have some limitations. For example, their computational load is great, and the correlation between assessment indices is not considered [19] sufficiently; besides, the occurrence of debris flow hazards have great complexity, fuzziness, and randomness, and these characteristics are ignored in the evaluation process.

To overcome the above shortcomings, a new evaluation method is suggested based on the entropy weight-normal cloud method in the paper. When the normal cloud model is combined with an entropy method, not only the correlation among different indices are solved successfully but also the conversion between qualitative and quantitative concepts can also be realized; besides, the randomness with fuzziness is considered; nowadays, the entropy weight-normal cloud is widely used in many fields [20] due to the above virtues, but 
few studies about the method have been applied to evaluate the risk of debris flow; the method is used to determine the risk level of debris flow in the paper.

The paper is organized as follows: in Section 2, the engineering background in the study area is introduced at first; in Section 3, a new risk assessment method of debris flow is introduced based on the cloud model and the entropy weight algorithm; in Section 4, the entropy-normal cloud model is established about debris flow in Banshanmen gully, and the assessment results of the proposed cloud model method are obtained; in Section 5, conclusions are drawn.

\section{Study Area}

The Banshanmen gully is located in the eastern region in Danba County, SiChuan Province, China; and it is siting on the left of Xiaojin River, as shown in Figure 1. Its geographic coordinate is northern latitude $30^{\circ} 59^{\prime} 52^{\prime \prime}$ and eastern longitude $102^{\circ} 03^{\prime} 10^{\prime \prime}$; it is composed of a main ditch and nine large branch ditches; its distribution map of river valley and source of matter is plotted in Figure 2. The plane of ditch valley presents strip shape; its drainage area is about $67.8 \mathrm{~km}^{2}$; the height of a maximum point on the ditch source is $4810 \mathrm{~m}$, the minimum height is $2093 \mathrm{~m}$, and their height difference is $2717 \mathrm{~m}$. The main ditch has lots of bends, the mean longitudinal slope is $133 \%_{0}$. Branch ditches are situated on the left of the main ditch; its mean longitudinal slope is $255 \sim 557 \%_{0}$. The average rainfall in a year is from $512 \mathrm{~mm}$ to $615 \mathrm{~mm}$; the rainfall from May to September arrives at $460 \mathrm{~mm}$, and it accounts for $75.4 \%$ in the whole year. Its static reserves of the solid source are about $185.43 \times 10^{4} \mathrm{~m}^{3}$, especially dynamic reserves arrive at $37.39 \times 10^{4} \mathrm{~m}^{3}$. The copious solid resource, abundant rainfall plus steep terrain result in the occurrence of debris flow hazards, so it is necessary to evaluate the risk level of debris flow in Banshanmen gully. The whole picture of debris flow is shown in Figure 3.

\section{Methodology}

3.1. The Construction of Assessment Frame. The occurrence of debris flow not only influence the normal operation of road traffic but also endanger the life and property security of people. Consequently, the risk assessment of debris flow hazards has important significance.

A new assessment method of debris flow is suggested; it is based on the normal cloud model, as presented in Figure 4. At first, to evaluate the risk level of debris flow, a complete assessment index system is built. Secondly, the weight of each evaluation index is calculated by an entropy weight algorithm. Thirdly, the numerical characteristics of the cloud are obtained by the normal cloud model theory. Finally, the magnitudes of synthetic certainty are performed, and the risk level of debris flow is determined.

3.2. Assessment Index System. There are many factors that resulted in the debris flow hazards, according to corresponding documents [21]; there are seven assessment indices that caused the debris flow hazards, and these indices

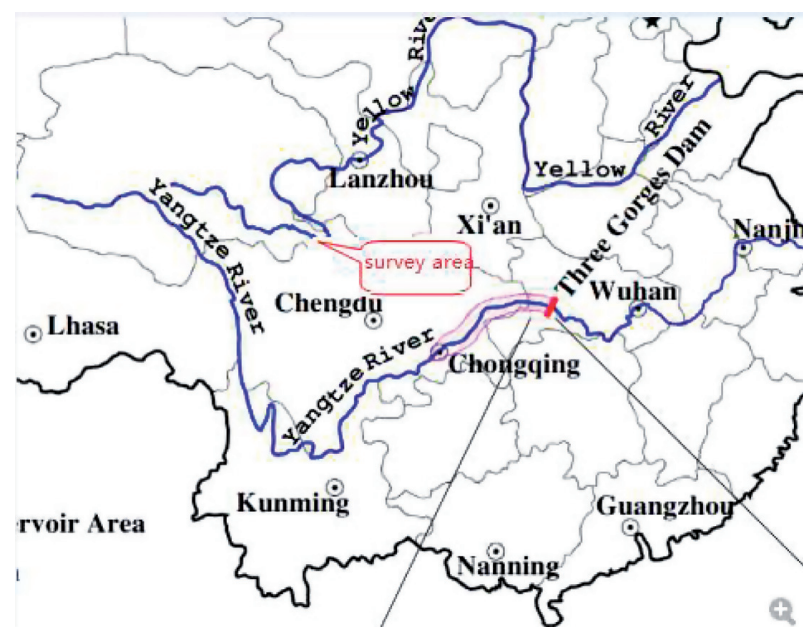

FIgURE 1: The geographical location of the study area.

are categorized as three conditions; they include topographic condition (e.g., the length of replenishment section $\left(X_{1}\right)$,longitudinal slope of main ditch $\left(X_{2}\right)$, the gradient of side slope $\left(X_{3}\right)$, the length of ditch $\left.\left(X_{4}\right)\right)$, source of matter (e.g., the reserves of loose substance $\left(X_{5}\right)$, the drainage area $\left(X_{6}\right)$ ), and rainfall condition (e.g., rainfall $\left(X_{7}\right)$ ). These assessment indices are all quantitative ones. The seven risk assessment indices have four levels: low risk (I), medium risk (II), high risk (III), and higher risk (IV), as shown in Table 1.

3.3. The Entropy Weight Theory. Entropy weighting method is defined as an average amount of information by using the concept of entropy; it is a method of calculating the weight of each index by using the magnitude of entropy [22]. The entropy is an index to measure the disorder and degree of confusion in a system [23]. Then, the occurrence of debris flow is a dynamic process affected by many indices; it is highly uncertain. Its calculative process is shown as follows:

(1) Assuming that there are $m$ cases of debris flow and $n$ assessment indices, so the original matrix can be expressed as

$$
X=\left[\begin{array}{cccc}
x_{11} & x_{12} & \ldots & x_{1 m} \\
x_{21} & x_{22} & \ldots & x_{2 m} \\
\ldots & \ldots & \ldots & \ldots \\
x_{n 1} & x_{n 2} & \ldots & x_{n m}
\end{array}\right]
$$

(2) Normalization treatment is conducted for the main indices $X_{i j}$, and its expressions are described as follows:

The positive indicator [24] is as follows:

$$
x_{i j}=\frac{x_{i j}-\min \left\{x_{i j}, \ldots, x_{n j}\right\}}{\max \left\{x_{1 j}, \ldots, x_{n j}\right\}-\min \left\{x_{i j}, \ldots, x_{n j}\right\}} .
$$

The negative indicator is as follows: 


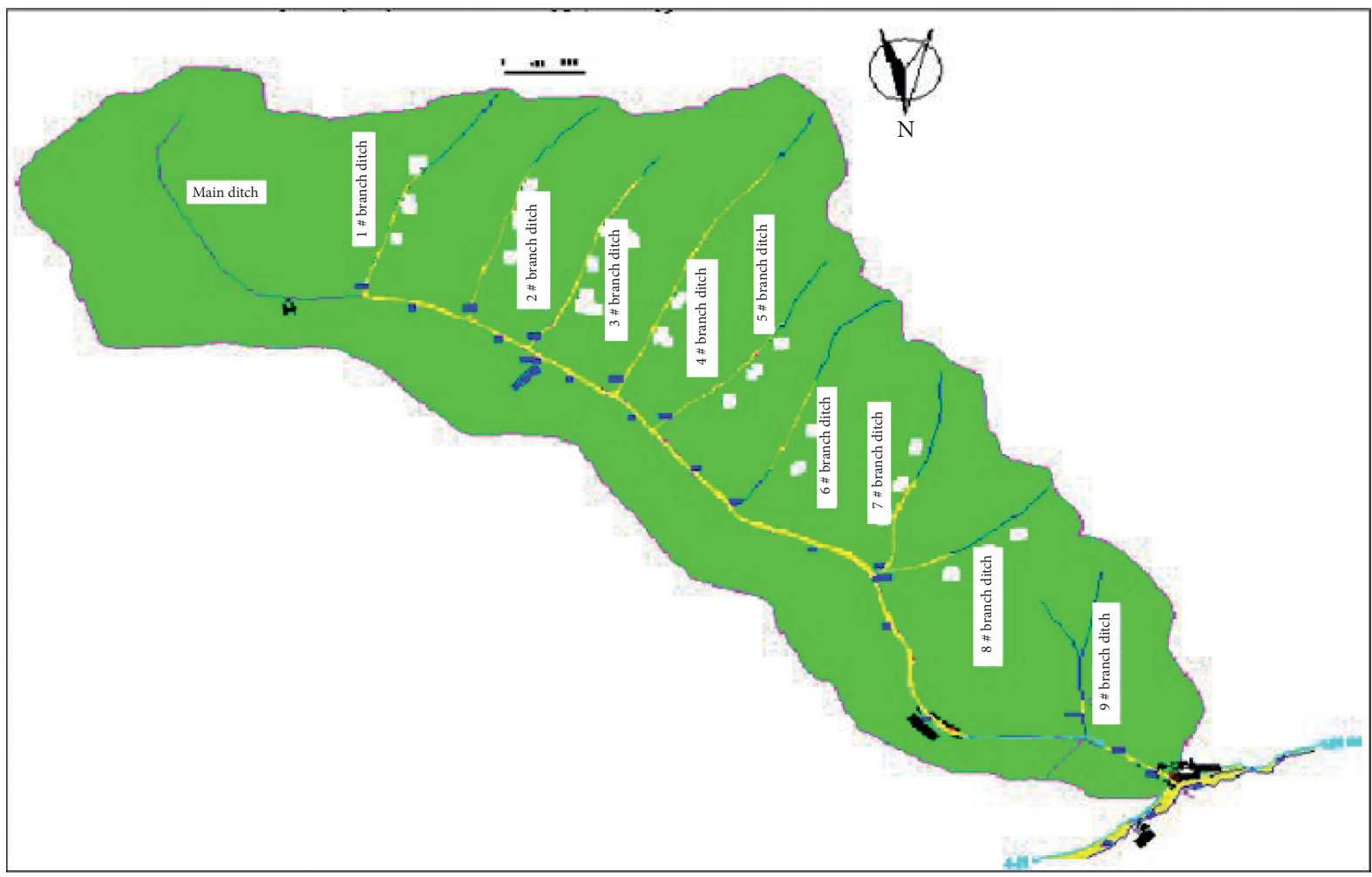

Mountainous region

Fluvial geomorphology

Figure 2: The zoning map of landforms.

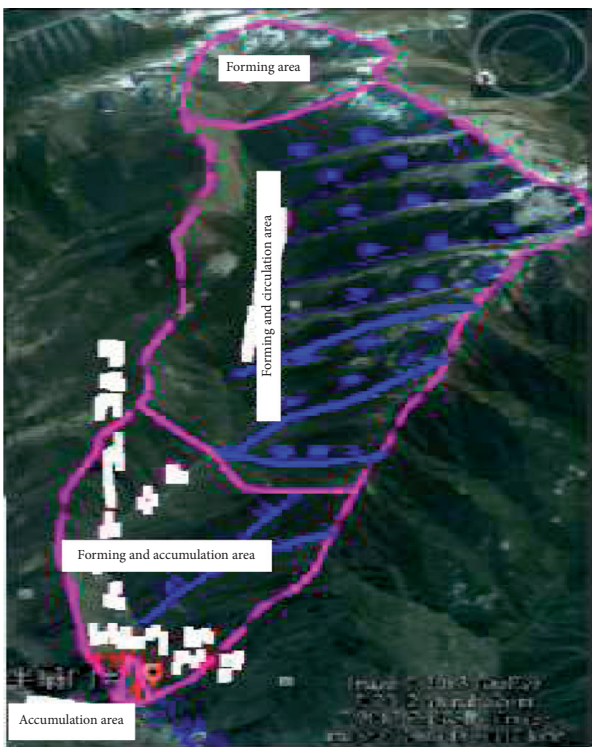

Figure 3: The whole picture about debris flow.

$$
x_{i j}^{\prime}=\frac{\min \left\{x_{1 j}, \ldots, x_{n j}\right\}-x_{i j}}{\max \left\{x_{1 j}, \ldots, x_{n j}\right\}-\min \left\{x_{i j}, \ldots, x_{n j}\right\}},
$$

where $i$ is assessment scheme; $j$ is assessment index, and $x_{i j}$ is the corresponding magnitude of the $j t h$ assessment index in the ith scheme $(i=1,2,3, \ldots, m ; j=1,2,3, \ldots, n)$.

(3) The determination of proportion about the $j t h$ evaluation index in the ith scheme is expressed as follows:

$$
b_{i j}=\frac{x_{i j}}{\sum_{i=1}^{n} x_{i j}} .
$$

(4) The entropy of $j$ th evaluation index is shown as follows:

$$
s_{j}=-k \sum_{i=1}^{n} b_{i j} \ln \left(b_{i j}\right)
$$

(5) The weight of $j$ th evaluation index is depicted as follows:

$$
\omega_{j}=\frac{1-s_{j}}{n-\sum_{j=1}^{n} s_{j}} .
$$

3.4. The Normal Cloud Model. The cloud model theory is constructed on the idea of fuzzy sets theory [25] and probability concepts [26], proposed by Li [27]. The cloud is defined as an uncertain transformation model between some qualitative concepts and quantitative ones; it represents uncertainty 


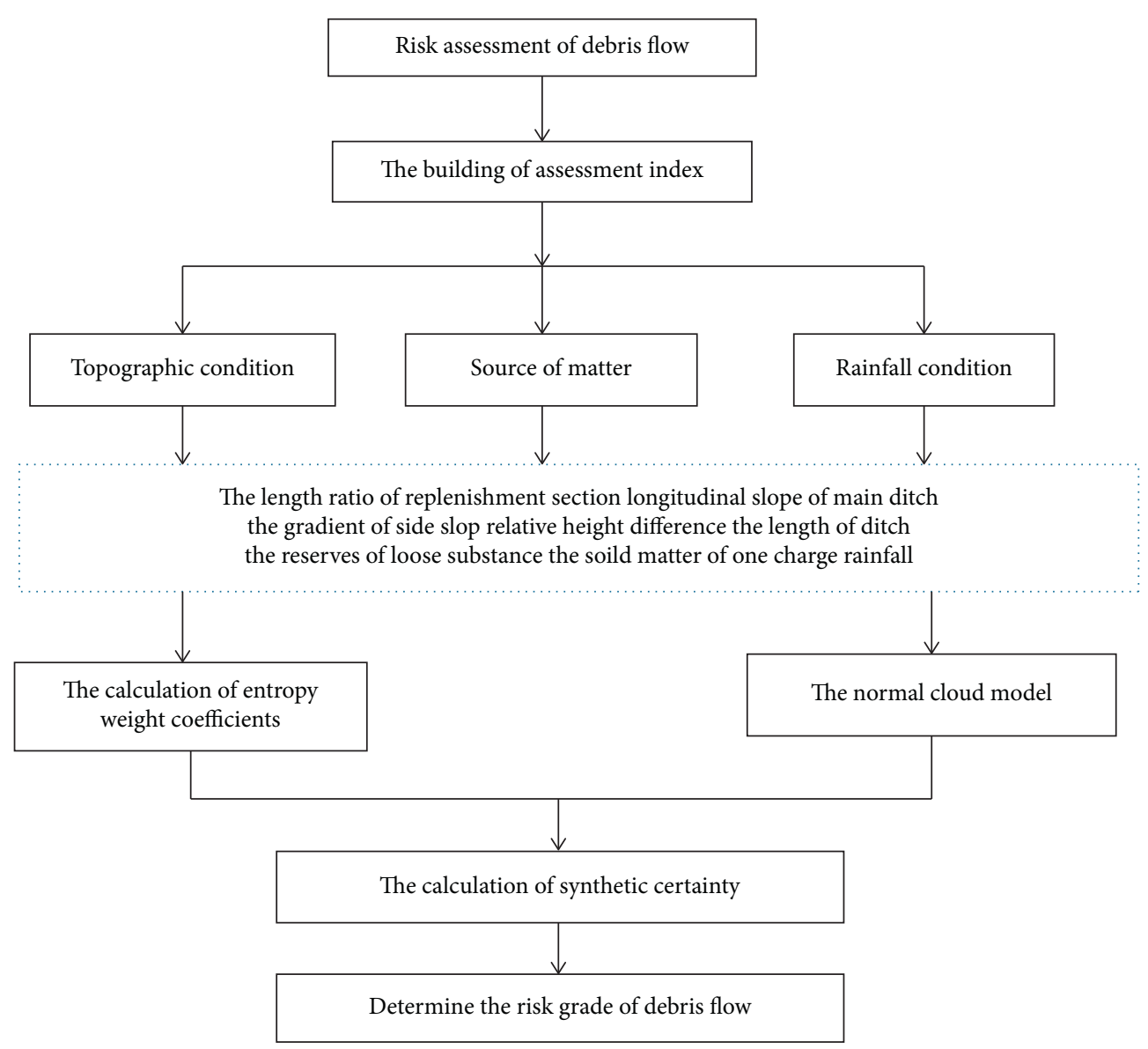

FIGURE 4: The risk assessment process of debris flow.

TABLe 1: The standard classification of assessment index about debris flow.

\begin{tabular}{lccccccc}
\hline \multirow{2}{*}{ Risk level } & \multicolumn{5}{c}{ Assessment indices } \\
& $X_{1}(\%)$ & $X_{2}\left(\%_{0}\right)$ & $X_{3}\left({ }^{0}\right)$ & $X_{4}(\mathrm{~km})$ & $X_{5}\left(10^{4} \mathrm{~m}^{3} / \mathrm{km}^{2}\right)$ & $X_{6}\left(10^{4} \mathrm{~m}^{3}\right)$ & $X_{7}\left(\mathrm{~mm}^{3}\right)$ \\
\hline I & $0 \sim 10$ & $0 \sim 52$ & $0 \sim 10$ & $0 \sim 1$ & $0 \sim 1$ & $0 \sim 1$ \\
II & $10 \sim 30$ & $52 \sim 105$ & $10 \sim 30$ & $1 \sim 5$ & $1 \sim 5$ & $1 \sim 10$ \\
III & $30 \sim 60$ & $105 \sim 213$ & $30 \sim 50$ & $5 \sim 10$ & $5 \sim 10$ & $50 \sim 100$ \\
IV & $>60$ & $>213$ & $50 \sim 90$ & $>10$ & $>10$ & $10 \sim 35$ & $>0 \sim 500$ \\
\hline
\end{tabular}

(including the randomness and fuzziness) of knowledge concept for things or person in nature. It constitutes the mapping between qualitative concepts and quantitative ones.

Let $U$ be a quantitative universe including exact values, and $M$ be the qualitative concept connected with $U$. If the qualitative value $x$ belongs to $U, x$ is a random implementation by using the qualitative concept $M$. The certainty degree $\mu(x) \in[0,1]$ of $x$ relative to a qualitative concept $M$ is the random variable with steady tendency; it can be expressed as follows:

$$
\mu: U \longrightarrow[0,1], \quad \forall x \in U, x \longrightarrow \mu(x),
$$

where the distribution of $x$ in qualitative domain $U$ is called as the cloud, and every $x$ is called as a cloud droplet, which is a tool as a quantitative meaning to describe a qualitative concept.
The numerical characteristics of cloud are defined as the representative of the whole about the concept of cloud based on the normal cloud and normal membership function distributions. The distribution of $x$ can be determined by three numerical eigenvalues $\left(E_{X}, E_{N}\right.$, and $\left.H_{e}\right) ; E_{X}$ is an expectation value in the universe of discourse and the best characterization of a qualitative concept [28]; $E_{n}$ is the entropy of $E_{X}$, and it represents a discrete degree of a cloud droplet in the distribution; $H_{e}$ represents the measure of uncertain degree for entropy, namely, it is the entropy of entropy; Their eigenvalue in the normal cloud distribution is shown in Figure 5.

The transformation process from qualification to quantification is called as the positive cloud generator. On the contrary, it is called as the negative cloud generator. Only the forward cloud generator in the paper is used, and the 


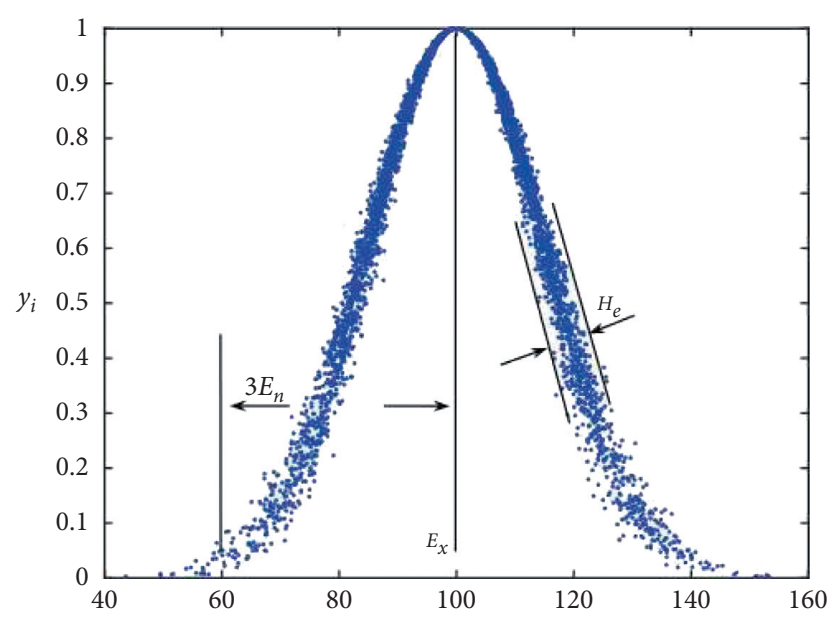

FIgURE 5: The sketch map about the eigenvalue of cloud.

backward cloud generator is omitted. Its transformation process is listed as follows: at first, the suitable cloud droplet is generated by using $C G \sim N^{3}\left(E_{x}, E_{n}, H_{e}\right)$, the production process of cloud drops represents the uncertainty of conversion between qualitative concept and quantitative values. Then, $n$ cloud droplets are composed of the cloud, so the qualitative concept is transformed as a quantitative expression by using the uncertainty of cloud model, and its process is shown in Figure 6.

Its specific algorithm in Figure 6 is listed as follows:

(1) Expectation $E_{n}$ and the standard deviation $H_{e}$ are, respectively, calculated.

(2) The normal random number $E_{n}^{*}$ is generated according to the characteristic value $\left(E_{X}, E_{N}, H_{e}\right)$ of cloud, its expected value is $E_{n}$, and the standard deviation is $H_{e}$.

(3) A normal random number $x_{i}$ is generated, its expected value is $E_{x}$, and the standard deviation is $E_{n}$; $x_{i}$ represents a quantitative value of a qualitative concept.

(4) The certainty degree $\mu$ of the qualitative concept $C$ is expressed according to procedures (1), (2), and (3).

$$
\mu=\exp \left[-\frac{\left(x-E_{x}\right)^{2}}{\left(2 E_{n}^{*}\right)^{2}}\right] \text {. }
$$

(5) The cloud droplet with the certainty degree $\mu$ and normally random number $x_{i}$ are, respectively, generated. Then, repeating procedures (1) to (4) until $N$ cloud droplets are generated.

\section{The Establishment of Risk Assessment Model about Debris Flow}

4.1. The Determination of Assessment Index's Weight. Due to the randomness and fuzziness of debris flow's occurrence, the normal cloud model can be established in the

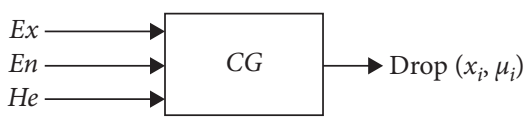

Figure 6: The forward cloud generator.

paper. Seven assessment indices are selected, each assessment index is depicted in Table 1. These indices are all positive assessment indices. The positive assessment indices denote that the risk level is lower as the magnitudes of these indices increases. Otherwise, they are defined as a negative assessment index. At first, to evaluate the weight coefficients of each assessment index, the original data of seven assessment indices are listed in Table 2.

According to Table 2 and equation (4), specific gravity matrix of each index can be shown in Table 3 .

According to Table 3 and combining with equations (4) and (5), the index entropy matrix of every index is shown in Table 4.

Based on equation (6), the weight coefficients of every index can be obtained in Table 5 .

4.2. The Normal Cloud Model of Debris Flow. To reflect the randomness and fuzziness, the risk assessment model about debris flow is established, and its assessment procession is listed as follows:

(1) The index and evaluation sets are, respectively, set up to assess the risk level of debris flow in Banshanmen gully at first. In the paper, the datum in Table 2 is regarded as the index sets $U=\left\{u_{1}, u_{2}, \ldots, u_{n}\right\}$; Table 1 is evaluation sets $V=\left\{v_{1}, v_{2}, \ldots, v_{n}\right\}$.

(2) The fuzzy matrix $M$ is established. To establish the matrix $M$, it is assumed that the upper and lower boundaries of the index $x_{i}$ are, respectively, $x_{l}$ and $x_{u}$, and then the qualitative concept $E_{x}$ of the index $x$ can be depicted as

$$
E_{x}=\frac{\left(x_{l}+x_{u}\right)}{2}
$$

Entropy can be expressed as follows:

$$
E_{n}=\frac{\left(x_{u}-x_{l}\right)}{6}
$$

And the hyper entropy $H_{e}$ is a constant which reflects the dispersion degree of the cloud model, where the hyper entropy $H_{e}$ is set as 0.01 .

Apart from that, if a variable has only a single boundary, like $\left[-\infty, x_{u}\right]$ or $\left[x_{l},+\infty\right]$, its default boundary parameters can be determined by the value of the upper or lower bounds as follows: 
TABLE 2: The synthetic parameters of debris flow.

\begin{tabular}{|c|c|c|c|c|c|c|c|}
\hline $\begin{array}{l}\text { Name of } \\
\text { ditch }\end{array}$ & $\begin{array}{c}\text { The length of } \\
\text { replenishment section } \\
X_{1}(\%)\end{array}$ & $\begin{array}{l}\text { Longitudinal slope of } \\
\text { main ditch } X_{2}(\%)\end{array}$ & $\begin{array}{l}\text { The gradient of } \\
\text { side slope } X_{3}\left(^{\circ}\right)\end{array}$ & $\begin{array}{l}\text { The } \\
\text { length of } \\
\text { ditch } X_{4} \\
(\mathrm{Km})\end{array}$ & $\begin{array}{c}\text { Reserves of } \\
\text { loose substance } \\
X_{5} \\
\left(10^{4} \mathrm{~m}^{3} / \mathrm{km}^{2}\right)\end{array}$ & $\begin{array}{l}\text { Drainage area } \\
X_{6}\left(\mathrm{~km}^{3}\right)\end{array}$ & $\begin{array}{l}\text { Rainfall } X_{7} \\
\quad(\mathrm{~mm})\end{array}$ \\
\hline Main ditch & 72 & 134 & 39 & 18.8 & 3 & 67.8 & 616 \\
\hline $\begin{array}{l}\text { 1\#branch } \\
\text { ditch }\end{array}$ & 60 & 255 & 43 & 3.41 & 3 & 4.89 & 601 \\
\hline $\begin{array}{l}\text { 2\#branch } \\
\text { ditch }\end{array}$ & 60 & 292 & 43 & 3.43 & 3 & 3.65 & 592 \\
\hline $\begin{array}{l}\text { 3\#branch } \\
\text { ditch }\end{array}$ & 60 & 264 & 43 & 3.14 & 3 & 3.32 & 581 \\
\hline $\begin{array}{l}\text { 4\#branch } \\
\text { ditch }\end{array}$ & 60 & 281 & 43 & 4.73 & 3 & 6.89 & 569 \\
\hline $\begin{array}{l}\text { 5\#branch } \\
\text { ditch }\end{array}$ & 60 & 344 & 43 & 3.25 & 3 & 3.31 & 579 \\
\hline $\begin{array}{l}\text { 6\#branch } \\
\text { ditch }\end{array}$ & 65 & 379 & 43 & 3.68 & 5 & 3.02 & 633 \\
\hline $\begin{array}{l}\text { 7\#branch } \\
\text { ditch }\end{array}$ & 67 & 450 & 53 & 3 & 10.2 & 3.14 & 642 \\
\hline $\begin{array}{l}\text { 8\#branch } \\
\text { ditch }\end{array}$ & 62 & 464 & 50 & 2.42 & 3 & 2.51 & 620 \\
\hline $\begin{array}{l}\text { 9\#branch } \\
\text { ditch }\end{array}$ & 62 & 557 & 53 & 2.37 & 3 & 3.78 & 618 \\
\hline
\end{tabular}

Table 3: The synthetic parameters of debris flow.

\begin{tabular}{|c|c|c|c|c|c|c|c|}
\hline $\begin{array}{l}\text { Name of } \\
\text { ditch }\end{array}$ & $\begin{array}{l}\text { The length of } \\
\text { replenishment } \\
\text { section } X_{1}(\%)\end{array}$ & $\begin{array}{l}\text { Longitudinal slope of } \\
\text { main ditch } X_{2}(\% o)\end{array}$ & $\begin{array}{l}\text { The gradient of } \\
\text { side slope } X_{3}\left({ }^{\circ}\right)\end{array}$ & $\begin{array}{l}\text { The length of } \\
\text { ditch } X_{4}(\mathrm{Km})\end{array}$ & $\begin{array}{c}\text { Reserves of loose } \\
\text { substance } X_{5} \\
\left(10^{4} \mathrm{~m}^{3} / \mathrm{km}^{2}\right)\end{array}$ & $\begin{array}{c}\text { Drainage area } \\
X_{6}\left(\mathrm{~km}^{3}\right)\end{array}$ & $\begin{array}{l}\text { Rainfall } X_{7} \\
\quad(\mathrm{~mm})\end{array}$ \\
\hline Main ditch & 0.1446 & 0.0392 & 0.0861 & 0.3898 & 0.0765 & 0.6627 & 0.1018 \\
\hline $\begin{array}{l}\text { 1\#branch } \\
\text { ditch }\end{array}$ & 0.0955 & 0.0746 & 0.0949 & 0.0707 & 0.0765 & 0.0478 & 0.0993 \\
\hline $\begin{array}{l}\text { 2\#branch } \\
\text { ditch }\end{array}$ & 0.0955 & 0.0854 & 0.0949 & 0.0711 & 0.0765 & 0.0357 & 0.0978 \\
\hline $\begin{array}{l}\text { 3\#branch } \\
\text { ditch }\end{array}$ & 0.0955 & 0.0772 & 0.0949 & 0.0651 & 0.0765 & 0.0325 & 0.096 \\
\hline $\begin{array}{l}\text { 4\#branch } \\
\text { ditch }\end{array}$ & 0.0955 & 0.0882 & 0.0949 & 0.0981 & 0.0765 & 0.0673 & 0.094 \\
\hline $\begin{array}{l}\text { 5\#branch } \\
\text { ditch }\end{array}$ & 0.0955 & 0.1006 & 0.0949 & 0.0674 & 0.0765 & 0.0324 & 0.0957 \\
\hline $\begin{array}{l}\text { 6\#branch } \\
\text { ditch }\end{array}$ & 0.1035 & 0.1108 & 0.0949 & 0.0763 & 0.1276 & 0.295 & 0.1046 \\
\hline $\begin{array}{l}\text { 7\#branch } \\
\text { ditch }\end{array}$ & 0.1067 & 0.1316 & 0.117 & 0.0622 & 0.2602 & 0.0307 & 0.1061 \\
\hline $\begin{array}{l}\text { 8\#branch } \\
\text { ditch }\end{array}$ & 0.0987 & 0.1357 & 0.1104 & 0.0502 & 0.0765 & 0.0245 & 0.1025 \\
\hline $\begin{array}{l}\text { 9\#branch } \\
\text { ditch }\end{array}$ & 0.0987 & 0.1629 & 0.117 & 0.0491 & 0.0765 & 0.0369 & 0 \\
\hline
\end{tabular}

TABle 4: The index entropy matrix.

\begin{tabular}{|c|c|c|c|c|c|c|c|}
\hline $\begin{array}{l}\text { Name of } \\
\text { ditch }\end{array}$ & $\begin{array}{l}\text { The length of } \\
\text { replenishment } \\
\text { section } X_{1}(\%)\end{array}$ & $\begin{array}{l}\text { Longitudinal slope of } \\
\text { main ditch } X_{2}(\% o)\end{array}$ & $\begin{array}{l}\text { The gradient of } \\
\text { side slope } X_{3}\left({ }^{\circ}\right)\end{array}$ & $\begin{array}{l}\text { The length of } \\
\text { ditch } X_{4}(\mathrm{Km})\end{array}$ & $\begin{array}{c}\text { Reserves of loose } \\
\text { substance } X_{5} \\
\left(10^{4} \mathrm{~m}^{3} / \mathrm{km}^{2}\right)\end{array}$ & $\begin{array}{c}\text { Drainage area } \\
X_{6}\left(\mathrm{~km}^{3}\right)\end{array}$ & $\begin{array}{l}\text { Rainfall } X_{7} \\
\quad(\mathrm{~mm})\end{array}$ \\
\hline $\begin{array}{l}\text { Index } \\
\text { entropy }\end{array}$ & 0.9992 & 0.9736 & 0.9978 & 0.8674 & 0.9496 & 0.5926 & 0.9997 \\
\hline
\end{tabular}


TABLe 5: The weight coefficient matrix.

\begin{tabular}{|c|c|c|c|c|c|c|c|}
\hline $\begin{array}{l}\text { Name of } \\
\text { ditch }\end{array}$ & $\begin{array}{c}\text { The length of } \\
\text { replenishment section } \\
X_{1}(\%)\end{array}$ & $\begin{array}{c}\text { Longitudinal slope } \\
\text { of main ditch } X_{2} \\
(\% \mathrm{o})\end{array}$ & $\begin{array}{c}\text { The gradient } \\
\text { of side slope } \\
X_{3}\left({ }^{\circ}\right) \\
\end{array}$ & $\begin{array}{l}\text { The length } \\
\text { of ditch } X_{4} \\
(\mathrm{Km})\end{array}$ & $\begin{array}{c}\text { Reserves of loose } \\
\text { substance } X_{5} \\
\left(10^{4} \mathrm{~m}^{3} / \mathrm{km}^{2}\right) \\
\end{array}$ & $\begin{array}{c}\text { Drainage } \\
\text { area } X_{6} \\
\left(\mathrm{~km}^{3}\right) \\
\end{array}$ & $\begin{array}{l}\text { Rainfall } X_{7} \\
\quad(\mathrm{~mm})\end{array}$ \\
\hline $\begin{array}{l}\text { Weight } \\
\text { coefficients }\end{array}$ & 0.0013 & 0.0425 & 0.0035 & 0.2139 & 0.0813 & 0.6569 & 0.0005 \\
\hline
\end{tabular}

Table 6: The fuzzy matrix $M$ of normal cloud standard classification about debris flow.

\begin{tabular}{lccccccc}
\hline \multirow{2}{*}{ Risk level } & & \multicolumn{5}{c}{ Assessment indices } \\
& $X_{1}(\%)$ & $X_{2}\left(\%_{0}\right)$ & $X_{3}\left({ }^{0}\right)$ & $X_{4}(\mathrm{~km})$ & $X_{5}\left(10^{4} \mathrm{~m}^{3} / \mathrm{km}^{2}\right)$ & $X_{6}\left(10^{4} \mathrm{~m}^{3}\right)$ & $X_{7}\left(\mathrm{~mm}^{3}\right)$ \\
\hline I & $(5,1.667,0.01)$ & $(26,8.667,0.01)$ & $(5,1.667,0.01)$ & $(0.5,0.167,0.01)$ & $(0.5,0.167,0.01)$ & $(0.5,0.167,0.01)$ & $(25,8.333,0.01)$ \\
II & $(20,3.333,0.01)$ & $(78.5,8.833,0.01)$ & $(20,3.333,0.01)$ & $(3,0.667,0.01)$ & $(3,0.667,0.01)$ & $(5.5,1.5,0.01)$ & $(75,8.333,0.01)$ \\
III & $(45,5,0.01)$ & $(159,18,0.01)$ & $(40,3.333,0.01)$ & $(7.5,0.833,0.01)$ & $(7.5,0.833,0.01)$ & $(22.5,4.167,0.01)$ & $(300,66.7,0.01)$ \\
IV & $(80,6.667,0.01)$ & $(319.5,53.25,0.01)$ & $(70,6.667,0.01)$ & $(15,2.5,0.01)$ & $(15,2.5,0.01)$ & $(52.5,8.75,0.01)$ & $(750,125,0.01)$ \\
\hline
\end{tabular}

$$
\begin{aligned}
& E_{x}=1.5 x_{l}, \\
& E_{n}=\frac{E_{x}}{6} .
\end{aligned}
$$

According to equations (9) to (12), evaluation sets $V=\left\{v_{1}, v_{2}, \ldots, v_{n}\right\}$ can be transformed into the fuzzy matrix $M$.

(3) The final mean membership degree $T_{i j}$ can be determined according to the assessment indices of debris flow.

$$
T_{i j}=\frac{\sum_{i=1}^{n} t_{i j}^{m}}{N}
$$

where $t_{i j}^{m}$ is the value generated from the forward generator in $m$ th time; $N$ is calculative time.

(4) The comprehensive certainty degree of the risk levels about debris flow can be depicted as

$$
P_{j}(n)=\sum_{i} \omega_{i} \cdot M_{i j}
$$

where $P_{j}(n)$ is the comprehensive certainty degree of corresponding risk level $j$ of the branch ditch $n ; \omega_{i}$ is the weight coefficient of the ith assessment index of the $n t h$ branch ditch. And $M_{i j}$ is the $j t h$ assessment level's average certainty degree of the ith assessment index.

Finally, the risk assessment level of the branch ditch $n$ can be obtained as follows:

$$
L=\max \left(P_{1}, P_{2}, P_{3}, P_{4}\right) .
$$

4.3. Risk Level Assessment. According to Table 1 and in combination with equations (9)-(12), the fuzzy matrix $M$ of normal cloud standard classification about debris flow as shown in Table 6.
The risk level of debris flow is determined by the maximum synthetic certainty degree, and the distributions of the certainty degrees about each evaluation index in the four risk levels of debris flow are plotted in Figure 7. In Figure 7, abscissa is the value of each assessment index, and the ordinate is the corresponding value of the certainty degree.

Based on normal cloud model theory, the process can be listed as follows:

(1) The standard of risk assessment about debris flow can be determined, and it is divided into four levels. Then, the numerical characteristics of fuzzy matrix $M$ can be obtained according to equations (9)-(12).

(2) According to the entropy weight theory, the weights of different indices are shown in Table 5 by equations (1) $-(6)$.

(3) Based on the obtained fuzzy matrix $M$ and the weights, the comprehensive certainty degree can be obtained by equations (13)-(15), and the final evaluation results can be shown in Table 7 .

The procedure of forward cloud generator about debris flow run by MATLAB calculated the datum from Table 2 about 2000 times. Finally, a comprehensive certain degree is obtained. And it is compared with the actual investigation results. The results are listed in Table 7 .

In Table 7 , each branch ditch can be generally classified by four levels from low to high. The final level of 1, 2, 3, 5, 6, 7 , and $8 \#$ branch ditch are II. One of $4 \#$ branch ditch is III. The final level of the main ditch is IV.

According to the comparative analysis of the assessment results in Table 7 , the results assessed by using two different methods are basically consistent in different branch ditches, except the $4 \#$ branch ditch. Its accurate rate arrives at $90 \%$, and conclusions are drawn that it is feasible to estimate the risk level of debris flow by using the normal cloud model. The cloud model not only achieves transformation between qualitative concepts and quantitative characteristics but also provides more details about the risk assessment levels. For example, drainage 

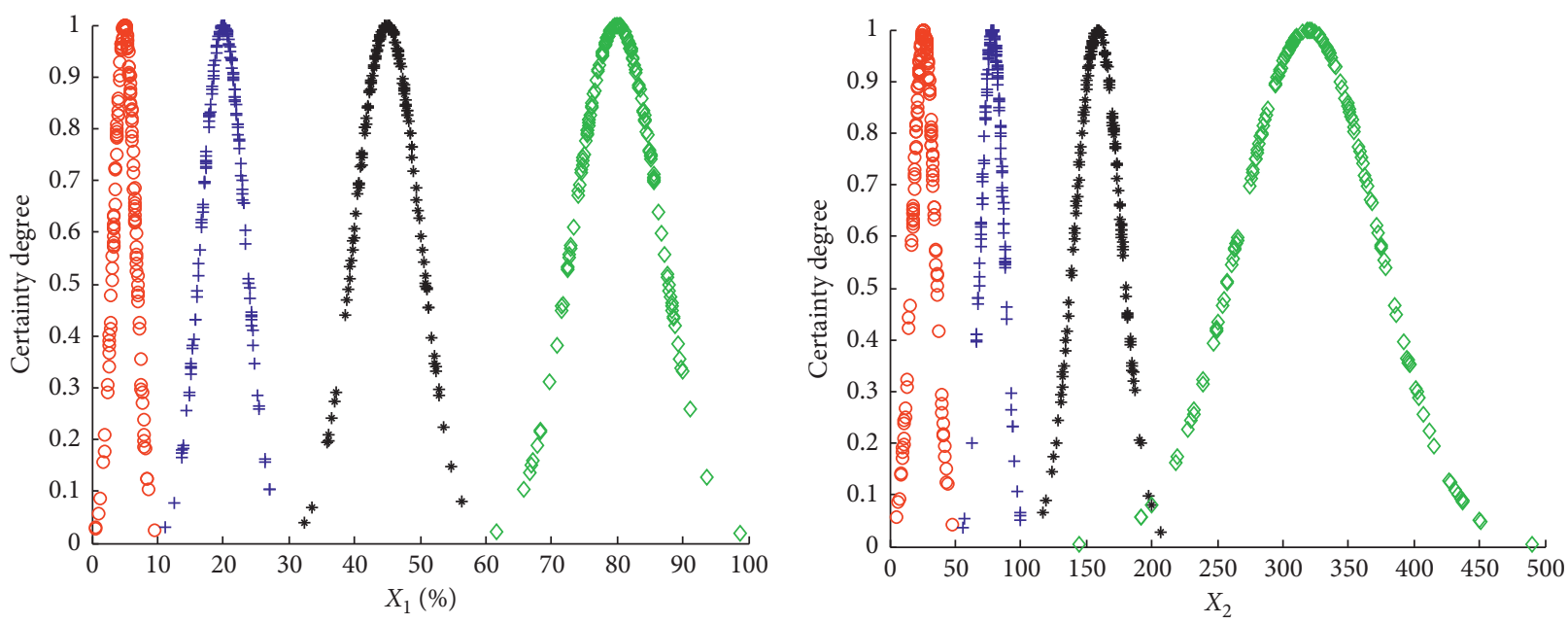

$$
\begin{array}{ll}
\circ \mathrm{I} & * \text { III } \\
+\mathrm{II} & \diamond \mathrm{IV}
\end{array}
$$

(a)

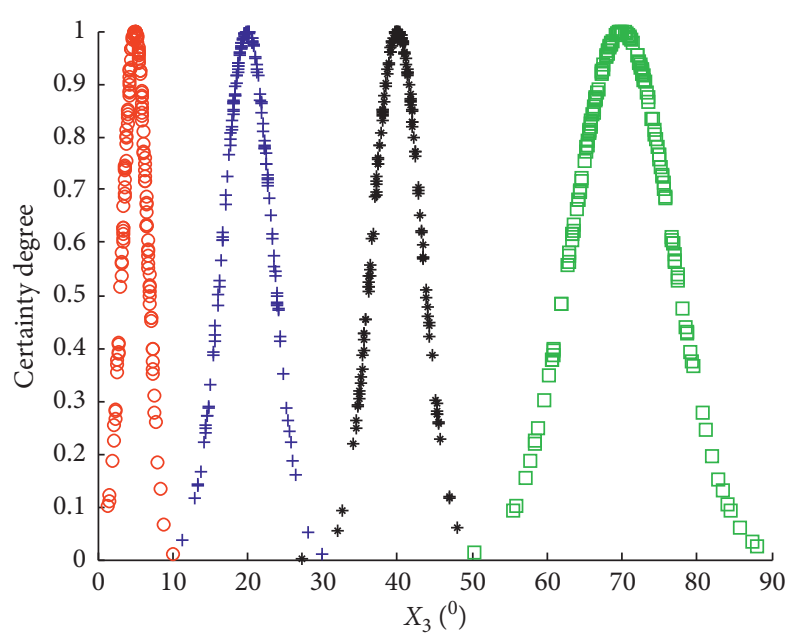

$\circ$ I

+ II
O I

+ II

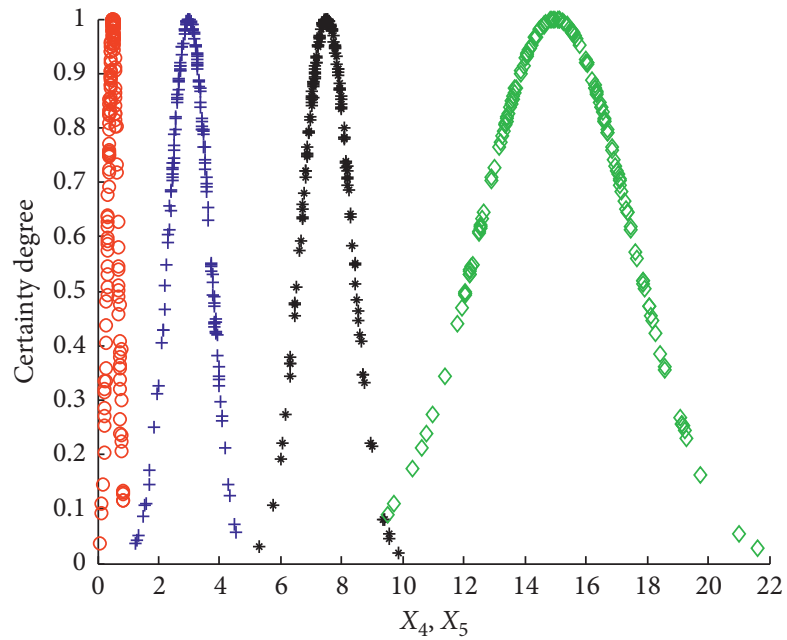

$\circ$ I

+ II

(c)
* III

$\diamond \mathrm{IV}$
* III

$\diamond \mathrm{IV}$

(b)

$$
\text { * III }
$$$$
\diamond \mathrm{IV}
$$

(d)

FIgURE 7: Continued. 


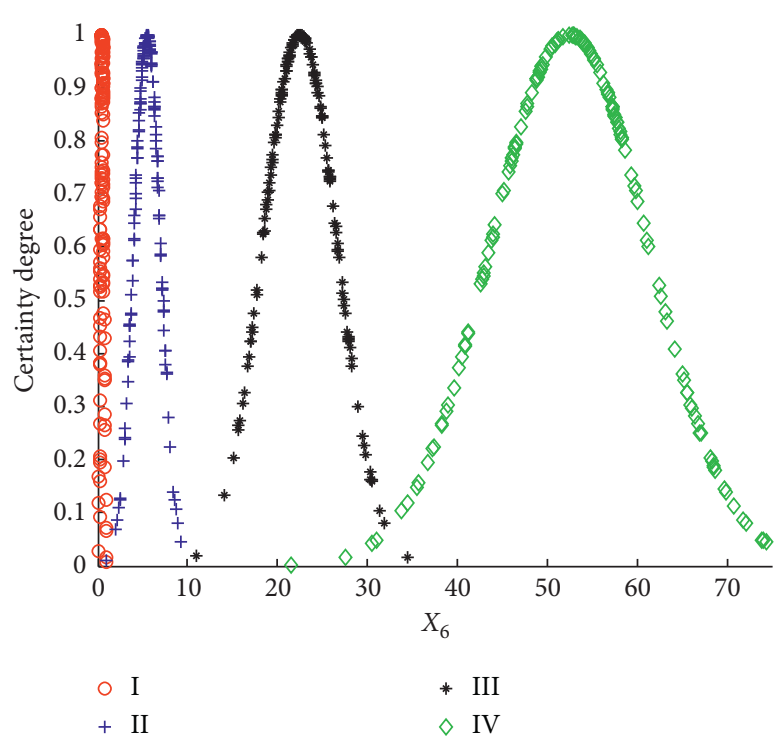

(e)

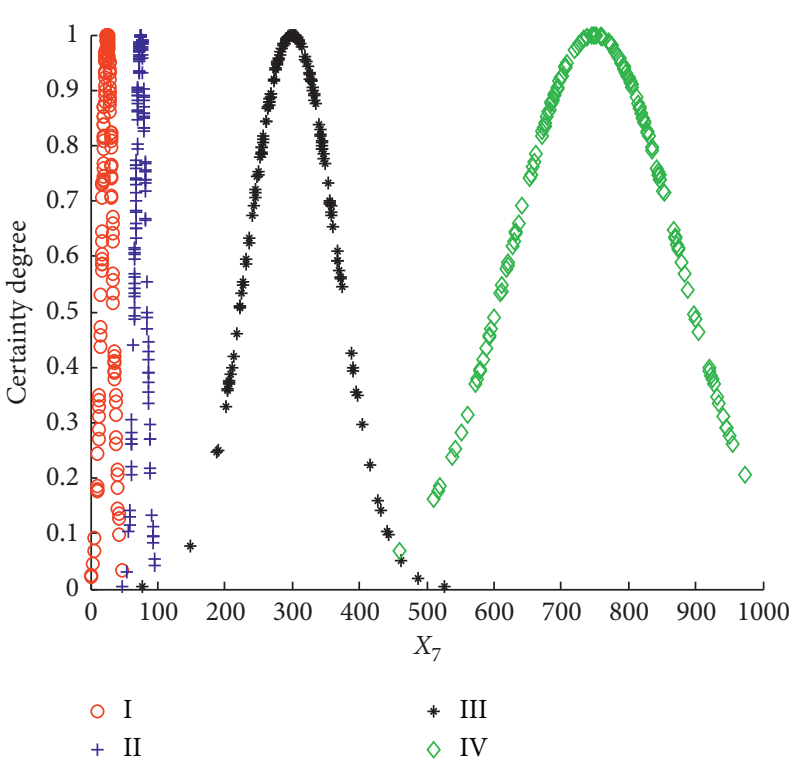

(f)

Figure 7: Cloud of each assessment index generated by the forward cloud generator. (a) The length of replenishment section $X_{1}$. (b) Longitudinal slope of main ditch $X_{2}$. (c) The gradient of side slope $X_{3}$. (d) The length of ditch $X_{4}$ and reserves of loose substance $X_{5}$. (e) The drainage area $X_{6}$. (f) Rainfall $X_{7}$

TABle 7: Comprehensive certainty degree.

\begin{tabular}{|c|c|c|c|c|c|c|}
\hline \multirow{2}{*}{ Member No } & \multicolumn{4}{|c|}{ The level of debris flow } & \multirow{2}{*}{ Comprehensive assessment } & \multirow{2}{*}{ Actual investigation } \\
\hline & $\mathrm{I}$ & II & III & IV & & \\
\hline Main ditch & 0 & 0.0813 & 0.0195 & 0.2108 & IV & IV \\
\hline 1\#branch ditch & 0 & 0.8629 & 0.0023 & 0.0206 & II & II \\
\hline 2\#branch ditch & 0 & 0.5621 & 0.0023 & 0.0374 & II & II \\
\hline 3\#branch ditch & 0 & 0.5191 & 0.0023 & 0.0249 & II & II \\
\hline 4\#branch ditch & 0 & 0.5161 & 0.0023 & 0.0329 & II & III \\
\hline 5\#branch ditch & 0 & 0.5069 & 0.0023 & 0.0384 & II & II \\
\hline 6\#branch ditch & 0 & 0.2955 & 0.0023 & 0.0231 & II & II \\
\hline 7\#branch ditch & 0 & 0.4043 & 0.0084 & 0.0155 & II & II \\
\hline $8 \#$ branch ditch & 0 & 0.3183 & 0 & 0.0014 & II & II \\
\hline 9\#branch ditch & 0 & 0.5699 & 0 & 0.0004 & II & II \\
\hline
\end{tabular}

area $X_{6}$ of $2 \#$ branch ditch is $3.65 \mathrm{~km}^{2}$, which should belong to grade II according to Table 1 . In addition, the certainty degrees of the drainage area obtained by the normal cloud generator are $\mu_{\mathrm{I}}=0.00, \mu_{\mathrm{II}}=0.4675$, $\mu_{\mathrm{III}}=0.0083$, and $\mu_{\mathrm{IV}}=0.0004$. Therefore, the certainty degree by quantitative analysis is $\mu_{\mathrm{II}}>\mu_{\mathrm{III}}>\mu_{\mathrm{IV}}>\mu_{\mathrm{I}}$, and the drainage area $X_{6}$ of $2 \#$ branch ditch only belongs to grade II and almost impossibly belongs to grades I, IV, and III. The conclusions are consistent with qualitative analysis. Furthermore, the level of $1 \#$ branch ditch is more likely to be level II than that of $2 \#, 3 \#$, and $4 \#$, because the certainty degree of $1 \#$ branch ditch for level II $(0.8629)$ is higher than that of $2 \#(0.7485), 3 \#(0.7485)$, and $4 \#$ (0.7485). In total, the results based on the normal cloud model not only reflect the risk level accurately but also further determine the risk ranking of debris flow for different branch ditches at the same level.

\section{Conclusions}

Considering the topographic condition, the source of matter, as well as rainfall condition, a new multi-index evaluation method is introduced in this paper to assess the risk level of debris flow in Banshanmen gully based on the entropy weight-normal cloud model. Required cloud drops are generated based on three numerical characteristics calculated by cloud generator algorithm. The weighting coefficients of the different indices were obtained by using entropy weighting method. The risk level of debris flow is determined by using the comprehensive certainty degree.

The present method is applied to the risk assessment of debris flow in Banshanmen gully. Finally, its results are compared with the actual investigation, and the calculated results obtained by two various methods are almost the same; its accurate rate arrives at $90 \%$. The results 
demonstrate final risk levels of the rest branch ditches except the $4 \#$ branch ditch are all level II. Besides, one of $4 \#$ branch ditch is level II, and one of the main ditch is level IV. In other words, the risk degree ranking of the main ditch is the highest. And the next it is the 4 \# branch ditch. Finally, one of the other branch ditches is the lowest. In all, the results of the proposed entropy weight-normal cloud model are highly consistent with the investigation results. It not only reflects the risk level of debris flow accurately but also further determines the risk ranking of debris flow for different branch ditches at the same level. So for the risk level assessment of debris flow characterized as complexity, fuzziness, and randomness, a new method, and thoughts can be provided.

\section{Data Availability}

The data used to support the findings of this study are available from the corresponding author upon request.

\section{Conflicts of Interest}

The authors declare that they have no conflicts of interest.

\section{Acknowledgments}

This work was supported by the first batch of Natural Science Foundation of Sichuan Provincial Department of Education (no. 17ZA0270), the Cross Project in Nanyang Institute of Technology (no. 230067), National Natural Foundation in China (no. 41672357), The Start-Up Foundation (510126), and the Sichuan Science and Technology Program (no. 2020YJ0424).

\section{References}

[1] W. Wu, "Debris flow risk assessment based on grey correlation analysis method a case study of Yinpohe debris flow in Lushui County," Geological Disasters and Environmental Protection, vol. 3, 2017.

[2] J. Zhang and T. Yang, "Study of a roof water inrush prediction model in shallow seam mining based on an analytic hierarchy process using a grey relational analysis method," Arabian Journal of Geoscience, vol. 11, p. 153, 2018.

[3] Y. Xue, Y. Liu, F. Dang et al., "Assessment of the nonlinear flow characteristic of water inrush based on the brinkman and forchheimer seepage model," Water, vol. 11, no. 4, p. 855, 2019.

[4] H.-N. Wu, S.-L. Shen, S.-M. Liao, and Z.-Y. Yin, "Longitudinal structural modelling of shield tunnels considering shearing dislocation between segmental rings," Tunnelling and Underground Space Technology, vol. 50, p. 317, 2015.

[5] H.-M. Lyu, W.-J. Sun, S.-L. Shen, and A. Arulrajah, "Flood risk assessment in metro systems of mega-cities using a GISbased modeling approach," Science of The Total Environment, vol. 626, p. 101, 2018.

[6] X. Li and Y. Li, "Research on risk assessment system for water inrush in the karst tunnel construction based on GIS: case study on the diversion tunnel groups of the Jinping II hydropower station," Tunnelling and Underground Space Technology, vol. 40, p. 18, 2014.

[7] H. D. Chu and G. L. Xu, "Risk assessment of water inrush in karst tunnels based on two-class fuzzy comprehensive evaluation method," Arabian Journal of Geosciences, vol. 10, p. 179, 2017.

[8] H. Li and C. Wu, "Basinwide disaster loss assessments under extreme climate scenarios: a case study of the Kaoping river basin," Natural Hazards, vol. 86, 2017.

[9] G. L. Guo, R. Guo, J. F. Gu et al., "Application of grey theory in hazard assessment of debris flow disaster in zhouqu nanyu gully," Arid Land Geography, vol. 86, 2019.

[10] L. L. Cao, L. R. Xu, S. Y. Chen et al., "Assessment of debris flow hazard based on fuzzy network," Hydrogeology \& Engineering Geoloogy, vol. 42, no. 2, p. 144, 2014.

[11] W. Chen, G. M. Ren, and S. S. Zuo, "Fuzzy comprehensive evaluation method to judge dangerous degree of debris flow," Research of Soil and Water Conservation, vol. 13, no. 2, p. 138, 2006.

[12] L. T. Feng, "Distribution regularity and early warning evaluation of geological hazards in Lanzhou," Journal of Gansu Sciences, vol. 26, no. 5, p. 63, 2014.

[13] J. H. Wang, "The application of fuzzy comprehensive evaluation model based on analytic hierarchy process in risk assessment of debris flow gully in Kangle County," The Chinese Journal of Geological Hazard and Control, vol. 28, no. 3, p. 54, 2017.

[14] Q. F. Niu, "Susceptibility assessment of disaster environment for landslide hazard based on GIS in Lanzhou Area," Journal of Catastrophology, vol. 32, no. 3, p. 29, 2017.

[15] G. Q. Yu, "FLAC3D based debris flow risk analysis for the Sanyanyu stream basin," Northwestern Geology, vol. 44, no. 3, 2011.

[16] G. L. Guo, "Application of grey theory in hazard assessment of debris flow disaster in Zhouqu Nanyu gully," Arid Land Geography, vol. 12, no. 6, p. 1369, 2019.

[17] M. Zhang, "Hazard assessment of debris flow along highway of high altitude cold and intensity regions with aid of ArcGIS," The Chinese Journal of Geological Hazard and Control, vol. 31, no. 2, p. 24, 2020.

[18] X.-L. Yang and S. Zhang, "Risk assessment model of tunnel water inrush based on improved attribute mathematical theory," Journal of Central South University, vol. 25, no. 2, p. 379, 2018.

[19] X. Fu, J. Li, and J. Yu, "The grey relational analysis of external factors on rutting formation," Transporation Science \& Technology, vol. 32, 2018.

[20] X. T. Wang, S. C. Li, Z. H. Xu, J. Hu, D. D. Pan, and Y. G. Xue, "Risk assessment of water inrush in karst tunnels excavation based on normal cloud model," Transporation Science \& Technology, vol. 23, 2019.

[21] P. Bhuwani, F. Mamadou, and D. Bahram, "GIS-based assessment of debris fow hazards in Kulekhani Watershed, Nepal," Natural Hazards, vol. 101, p. 143, 2020.

[22] C. L. Chiu, "Entropy and probability concepts in hydraulics," Journal of Hydraulic Engineering, vol. 113, no. 5, pp. 583-599, 1987.

[23] V. P. Singh, "Entropy theory and its application in environmental and water engineering," John Wiley \& Sons, vol. $662,2020$.

[24] D. Mirauda, A. de Vincenzo, and M. Pannone, "Statistical characterization of flow field structure in evolving braided gravel beds," Spatial Statistics, vol. 34, 2019.

[25] J. Moon and G. Fernandez, "Effect of excavation-induced groundwater level drawdown on tunnel inflow in a jointed rock mass," Engineering Geology, vol. 110, no. 3-4, pp. 33-42, 2010. 
[26] L. Li, T. Lei, S. Li et al., "Risk assessment of water inrush in karst tunnels and software development," Arabian Journal of Geosciences, vol. 8, no. 4, pp. 1843-1854, 2015.

[27] S. C. Li and J. Wu, "A multi-factor comprehensive risk assessment method of karst tunnels and its engineering application," Bulletin of Engineering Geology and the Environment, vol. 78, no. 3, pp. 1761-1776, 2019.

[28] Z. H. Xu, S. C. Li, and L. P. Li, "Risk assessment of water or mud inrush of karst tunnels based on analytic hierarchy process," Rock Soil Mechanism, vol. 32, pp. 1757-1766, 2011. 